\title{
Upaya Meningkatkan Keterampilan Motorik Kasar Melalui Kegiatan Senam Ritmik
}

\author{
Agni Firdaus ${ }^{1}$, Yuyun Yulianingsih ${ }^{2}$, Tuti Hayati ${ }^{3}$ \\ 1. Raudhatul Athfal Jadaria, Cibiru Wetan Kecamatan Cileunyi Kabupaten Bandung \\ ${ }^{2.3}$ Universitas Islam Negeri Sunan Gunung Djati Bandung, Jalan A.H. Nasution No. 105 \\ Bandung 40614 \\ Email: agnifirdausda5@gmail.com ${ }^{1}$
}

\begin{abstract}
Abstrak
Observasi awal yang dilakukan pada anak di kelompok A RA Jadaria bahwa keterampilan motorik kasar anak belum optimal. Hal ini terbukti masih adanya anak yang belum mampu menggerakkan otot besarnya. Tujuan penelitian ini untuk mengetahui keterampilan motorik kasar anak sebelum dan sesudah diterapkan kegiatan senam ritmik, dan penerapan kegiatan senam ritmik untuk meningkatkan motorik kasar. Metode yang digunakan adalah Penelitian Tindakan Kelas (PTK) yang terdiri dari dua siklus. Metode PTK meliputi: planning, acting, observing, and reflecting. Teknik pengumpulan data yang digunakan ialah observasi, unjuk kerja, dan dokumentasi. Adapun hasil penelitian menunjukkan bahwa keterampilan motorik kasar anak sebelum diterapkan kegiatan senam ritmik diperoleh nilai 46,17 dengan kategori kurang sekali, sedangkan setelah diterapkan kegiatan senam ritmik pada siklus I diperoleh nilai 55,28 dengan kategori kurang. siklus II diperoleh nilai 78,35 dengan kategori baik. Adapun penerapan senam ritmik untuk meningkatkan keterampilan motorik pada aktivitas guru siklus I diperoleh rata-rata $75 \%$ dengan kriteria cukup, dan pada siklus II diperoleh rata-rata $95 \%$ dengan kriteria sangat baik. Demikian pula hasil analisis aktivitas anak pada siklus I diperoleh rata-rata 49,65\% dengan kategori kurang sekali, dan pada siklus II diperoleh rata-rata $71,82 \%$ dengankategori cukup. Dengan demikian hipotesis yang diajukan diterima, artinya kegiatan senam ritmik dapat meningkatkan keterampilan motorik kasar anak.
\end{abstract}

Kata kunci: Keterampilan Motorik Kasar, Penelitian Tindakan Kelas, Senam Ritmik.

\section{Abstract}

Preliminary observations made on children in A RA Jadaria group that children's gross motor skills were not optimal. This is evident that there are still children who have not been able to move their large muscles. The purpose of this study was to find out: gross 
motor skills of children before and after applied rhythmic exercise activities, and the application of rhythmic gymnastic activities to improve gross motor. The method used is PTK which consists of two cycles. PTK methods include: planning, acting, observing and reflecting. Data collection techniques used are observation, performance and documentation. The results of the study showed that: The gross motor skills of children before being applied to rhythmic gymnastic activities obtained a value of 46.17 with very less category. while after applying rhythmic exercise activities in cycle I obtained a value of 55.28 with less category, cycle II obtained a value of 78.35 with good category. As for the application of rhythmic gymnastics to improve motor skills in teacher activity cycle I obtained an average of $75 \%$ with sufficient criteria, and in cycle I/ obtained an average of $95 \%$ with very good criteria. Likewise, the results of the analysis of children's activities in the first cycle obtained an average of $49.65 \%$ with very poor categories, and in cycle II obtained an average of $71.82 \%$ with enough categories. Thus the proposed hypothesis is accepted, meaning that rhythmic gymnastic activities can improve children's gross motor skills.

Keywords: classroom action research, gross motor skills, rhythmic gymnastics.

\section{Pendahuluan}

Pendidikan Anak Usia Dini (PAUD) adalah suatu upaya pembinaan yang ditujukan kepada anak sejak lahir sampai usia enam tahun, dilakukan melalui pemberian rangsangan untuk membantu pertumbuhan dan perkembangan anak baik jasmani maupun rohani agar anak memiliki kesiapan dan keterampilan dalam memasuki pendidikan lebih lanjut. Pendidikan Anak Usia Dini dapat dilakukan melalui jalur pendidikan formal, non formal maupun informal misalnya Taman Kanak-Kanak (TK), Raudhatul Athfal (RA), Kelompok Bermain (Kober), Taman Penitipan Al-Qur'an (TPA), Pos PAUD, dan lembaga lain yang sederajat. Melalui program pendidikan anak usia dini diharapkan dapat memfasilitasi perkembangan anak secara optimal.

Pendidikan anak usia dini merupakan salah satu bentuk penyelenggaraan pendidikan yang menitikberatkan pada peletakan dasar ke arah pertumbuhan dan perkembangan. Pertumbuhan dan perkembangan itu diantaranya perkembangan moral dan agama, perkembangan fisik yang berhubungan dengan koordinasi motorik halus dan kasar, kecerdasan kognitif yang berkaitan dengan daya pikir serta daya cipta, sosio emosional menyangkut sikap dan emosi, dan yang terakhir bahasa, sesuai dengan keunikan dan tahap perkembangan pada kelompok usia yang dilalui oleh anak usia dini 
(Permendiknas No 58 Tahun 2009). Artinya, bahwa perkembangan dan pertumbuhan setiap anak itu berbeda, tergantung stimulasi yang guru atau orang tua berikan kepadanya maupun anugerah yang telah diberikan oleh Allah SWT kepada anak, yang dibekali dengan fitrah. Hal ini sesuai Hadis Nabi sebagai berikut:

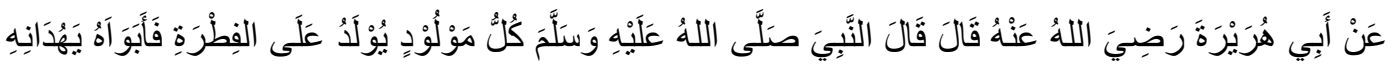

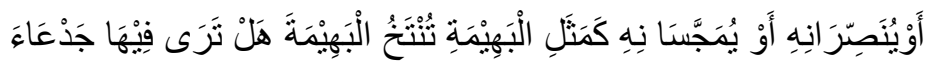

Dari Abu Hurairah Radiyallahu'an dia berkata: Nabi SAW telah bersabda "Setiap anak dilahirkan menurut fitrah. Selanjutnya, kedua orang tuanya yang menjadikannya Yahudi, Nasrani, atau Majusi bagaikan binatang yang melahirkan anaknya, apakah kamu melihat kekurangan padanya?"(H.R. Al-Bukhari).

Sejalan dengan pernyataan di atas, Umar (2012: 75) berpendapat bahwa yang mempengaruhi perkembangan anak dimanfaatkan oleh setiap orang tua secara maksimal. Orang tua harus menciptakan kondisi yang kondusif agar semua potensi anak dapat berkembang optimal. Apabila orangtua tidak mendidik anaknya atau melaksanakan pendidikan kepada anak tidak dengan sungguhsungguh, maka akibatnya anak tidak akan berkembang sesuai dengan harapan.

Salah satu perkembangan anak yang dapat distimulasi adalah perkembangan motorik. Perkembangan motorik menurut Sumantri (2005: 48) adalah perubahan kemampuan gerak dari bayi sampai dewasa yang melibatkan berbagai aspek perilaku dan kemampuan gerak. Jadi melalui pendidikan anak usia dini perkembangan gerak pada anak dapat distimulasi agar berkembang secara optimal. Kamtini (2005: 124) mengemukakan bahwa perkembangan motorik pada anak meliputi dua macam, yaitu perkembangan motorik kasar dan perkembangan motorik halus. Perkembangan keterampilan motorik kasar meliputi kegiatan seluruh tubuh atau bagian tubuh yang melibatkan bermacam koordinasi kelompok otot-otot tertentu. Perkembangan motorik halus menggunakan otot halus pada kaki dan tangan.

Berbagai cara dilakukan untuk mengembangkan motorik kasar agar anak dapat berkembang fisik motoriknya. Salah satu cara yang dapat membuat anak aktif dan membuat anak senang yaitu dengan menggunakan kegiatan senam. Senam merupakan cabang olahraga yang melibatkan performa gerakan yang membutuhkan kekuatan, kecepatan dan keserasian gerakan fisik yang teratur. Senam biasa digunakan orang untuk rekreasi, relaksasi atau menenangkan pikiran, biasanya ada yang melakukannya di rumah, di tempat fitness, dan gymnasium maupun di sekolah. Saat ini banyak anak 
yang sudah terbiasa diajarkan senam, baik oleh orang tua, maupun oleh pengajar olahraga di sekolah.

Berdasarkan hasil observasi awal di Kelompok A RA Jadaria Desa Cibiru Wetan Kecamatan Cileunyi Kabupaten Bandung diperoleh informasi, bahwa terdapat 13 anak dari 18 anak mengalami kesulitan dalam mengkoordinasikan anggota tubuhnya sehingga kondisi motorik kasar anak rendah, hal ini ditandai dengan (1) Anak kurang aktif dalam pembelajaran motorik, tampak selalu diam atau jarang bergerak sekalipun kondisi sedang sehat, hal ini terlihat ketika anak berbaris di depan kelas; (2) Anak kurang percaya diri, karena ketidak mampuan dalam melakukan kegiatan fisik motorik yang diberikan; (3) Malas dan tidak mau berusaha dalam setiap kegiatan yang membutuhkan tenaga; (4) Anak kurang mandiri atau tidak bisa melakukan aktivitas sendiri, sehingga setiap kegiatan selalu meminta bantuan orang lain.

Berdasarkan hal tersebut, penulis tertarik untuk melakukan penelitian yang berjudul Upaya Meningkatkan Keterampilan Motorik Kasar Melalui Kegiatan Senam Ritmik". Tujuan yang ingin dicapai dalam penelitian ini adalah untuk meningkatkan keterampilan motorik kasar dengan memaksimalkan kegiatan senam pada anak kelompok A RA Jadaria tahun ajaran 2018/2019.

\section{Metodologi}

Penelitian ini dilakukan di RA Jadaria Cibiru Wetan Kecamatan Cileunyi Kabupaten Bandung. Penelitian ini dilakukan di kelompok A RA Jadaria pada semester I Tahun Ajaran 2018/2019. Waktu penelitian dimulai bulan Juli sampai bulan Agustus. Subjek penelitian berjumlah 18 anak terdiri dari 11 anak laki laki dan tujuh anak perempuan.

Pendekatan dalam penelitian ini menggunakan pendekatan penelitian kualitatif dan kuantitatif atau disebut dengan pendekatan campuran (mix method). Sebagaimana pendapat dari Creswell (2016:5) bahwa penelitian campuran (mixed method) merupakan pendekatan penelitian yang melibatkan pengumpulan data kuantitatif dan kualitatif, penggabungan dua bentuk data dan penggunaan rancangan berbeda, yang dapat melibatkan asumsi-asumsi filosofis dan kerangka kerja teoritis.

Metode yang digunakan dalam penelitian ini adalah metode penelitian tindakan. Stephen Kemmis dari Universitas Deakin dan Wilf Carr dari Universitas College of North Wales tahun 1986, menjelaskan bahwa penelitian tindakan adalah sebuah bentuk penelitian refleksi diri yang melibatkan sejumlah partisipan (guru, peserta didik, kepala 
sekolah, dan partisipan lain) di dalam suatu situasi sosial (pembelajaran) yang bertujuan untuk membuktikan kerasionalan dan keadilan terhadap praktek sosial dan pembelajaran yang dilakukan, pemahaman terhadap praktek-praktek pembelajaran, serta situasi maupun institusi yang terlibat di dalamnya.

Penelitian tindakan kelas secara prosedur biasanya meliputi beberapa siklus yang disesuaikan dengan tingkat permasalahan yang akan dipecahkan dan kondisi yang akan ditingkatkan (Mulyasa, 2011:70). Tidak ada ketentuan berapa kali siklus yang harus dilakukan. Banyaknya siklus tergantung dari keputusan peneliti dan guru. Untuk lebih jelasnya dapat dilihat dalam model visualisasi bagan siklus Penelitian Tindakan Kelas (PTK) berikut ini:

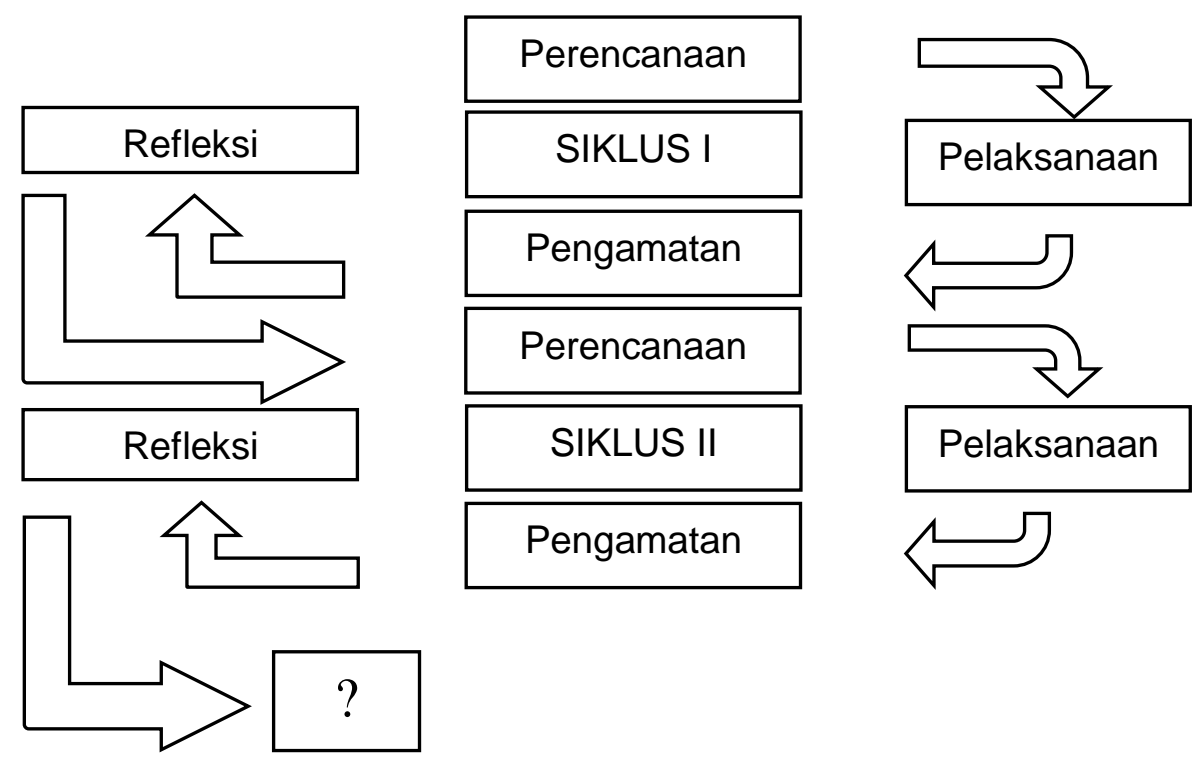

Gambar 1. Siklus Penelitian Tindakan Kelas Kemmis dan Mc Taggart

Penelitian ini dilakukan secara bersiklus yang terdiri dari proses perencanaan (planning), pelaksanaan (acting), observasi (observing), dan refleksi (reflecting). Kegiatan ini sesuai dengan model penelitian tindakan kelas yang dikemukakan Kemis \&Taggart (Akbar, 2010: 29). Hubungan keempat komponen tersebut dipandang sebagai siklus yang dapat dijelaskan sebagai berikut: (1) perencanaan, menurut Arikunto (2010: 17) bahwa perencanaan merupakan langkah yang dilakukan oleh guru ketika akan memulai tindakan. Pada tahap perencanaan, peneliti menyusun jadwal penelitian, menyiapkan skenario pembelajaran, menyiapkan instrumen untuk merekam dan menganalisis data mengenai proses dan hasil tindakan, serta menyiapkan alat dan bahan yang dibutuhkan dalam penelitian. (2) Pelaksanaan, tahapan ini peneliti berkolaborasi dengan guru melaksanakan suatu kegiatan pembelajaran sesuai dengan apa yang sudah direncanakan. Arikunto (2010: 17) menyebutkan bahwa pada tahap 
pelaksanaan tindakan adalah mengimplementasikan apa yang telah direncanakan. Pada tahap ini peneliti melakukan tindakan-tindakan yang telah dirumuskan dalam skenario pembelajaran, dalam situasi yang aktual, yang meliputi kegiatan awal, inti dan akhir. (3) Observasi/Pengamatan, peneliti dan guru melakukan pengamatan dan pencatatan terhadap gejala-gejala yang tampak terjadi selama proses kegiatan. Pengamatan dapat dilakukan dengan mengisi lembar observasi. Selain itu dapat pula menggunakan metode dokumentasi dengan mengambil foto/video anak ketika melakukan kegiatan senam. Pada tahap ini yang harus dilaksanakan adalah mengamati perilaku anak yang sedang mengikuti kegiatan senam ritmik. Selama proses kegiatan senam berlangsung dilaksanakan observasi oleh observer terkait kegiatan guru dan siswa selama pembelajaran senam ritmik. (4) Refleksi, setelah selesai melaksanakan kegiatan senam irama maka peneliti dan guru kelas melakukan refleksi terhadap proses pembelajaran yang telah dilakukan, mencari kelebihan dan kekurangan yang terjadi selama proses pembelajaran dari data yang diperoleh pada lembar observasi dianalisis, kemudian dilakukan refleksi. Pelaksanaan refleksi berupa diskusi antara peneliti dan guru kelas yang bersangkutan. Diskusi tersebut untuk mengevaluasi hasil tindakan yang dilakukan yaitu dengan cara melakukan penelitian terhadap proses yang terjadi, masalah yang muncul dan segala hal yang berkaitan dengan tindakan yang dilakukan. Setelah itu mencari jalan keluar terhadap masalah-masalah yang mungkin timbul agar dapat dibuat rencana perbaikan pada tahap kegiatan selanjutnya.

Jenis data dalam penelitian ini adalah data kualitatif dan kuantitatif. Menurut Arikunto (2010: 131) data kualitatif adalah data yang berbentuk kalimat, kata atau gambar. Data kualitatif merupakan penelitian yang diperoleh dari observasi. Penelitian ini berupa kondisi objektif sekolah, serta kegiatan belajar mengajar yang dilakukan selama proses belajar mengajar. Sedangkan data kuantitatif adalah data yang berbentuk angka.

Dalam melaksanakan pengumpulan data, peneliti menggunakan beberapa alat yang digunakan, yaitu (1) observasi, Sugiyono (2017: 145) berpendapat bahwa observasi merupakan suatu proses yang kompleks, suatu proses yang tersusun dari berbagai proses biologis dan psikologis. Observasi pada penelitian ini bertujuan untuk memperoleh gambaran tentang pelaksanaan pembelajaran motorik kasar anak melalui kegiatan senam ritmik. Aspek yang diobservasi adalah aktivitas anak dan guru selama proses pembelajaran. Observasi dilakukan oleh guru kelompok B RA Jadaria. Instrumen yang digunakan adalah lembar observasi aktivitas anak dan lembar observasi aktivitas guru. Masing-masing berisi kegiatan yang harus dilakukan oleh siswa dan guru sesuai 
dengan rencana pelaksanaan pembelajaran harian yang telah disusun sebelumnya; (2) Unjuk Kerja, Mulyasa (2014: 198) berpendapat bahwa unjuk kerja merupakan penilaian yang menuntut peserta didik untuk melakukan tugas dalam perbuatan yang dapat diamati, misalnya praktek menyanyi, olahraga, menari dan bentuk praktek lainnya. Instrumen unjuk kerja anak pada penelitian ini terdiri dari empat poin penilaian sesuai dengan unsur-unsur keterampilan motorik kasar yang ada pada kegiatan senam ritmik yaitu kelenturan, keseimbangan, kontinuitas gerakan, dan ketepatan dengan irama. Instrumen unjuk kerja ini bertujuan untuk mengetahui sejauh mana penerapan unsurunsur keterampilan motorik kasar yang ada pada kegiatan senam ritmik dalam setiap siklus pembelajaran; (3) Dokumentasi, dalam penelitian ini, dokumen yang digunakan berupa foto-foto untuk merekam kegiatan dalam setiap siklus senam yang dilakukan oleh anak. Sebagaimana pendapat dari Sugiyono (2016: 329) bahwa dokumen merupakan catatan peristiwa yang sudah berlalu.

Analisis data yang dilakukan dalam penelitian ini terbagi dalam dua bagian: (1) Analisi pengamatan observasi, analisis hasil pengamatan digunakan untuk menjawab rumusan masalah mengenai penerapan senam ritmik untuk meningkatkan keterampilan motorik kasar anak, serta aktivitas guru dan anak selama kegiatan senam ritmik menggunakan data berupa hasil lembar observasi yang dianalisis menggunakan data deskriptif kualitatif dengan mendeskripsikan aktivitas yang dilakukan selama proses belajar mengajar dengan menggunakan rumus:

a. Analisis data hasil aktivitas guru

$$
\text { Aktivitas guru dalam KBM }=\frac{\text { Jumlah aktivitas guru }}{\text { Jumlah Item indikator }} \times 100 \%
$$

b. Analisis data hasil aktivitas anak

$$
\text { Aktivitas anak dalam KBM }=\frac{\text { Jumlah aktivitas setiap anak }}{\text { Jumlah Item indikator } x \text { skor maksimal }} \text { X 100\% }
$$

Setelah diperoleh jumlah aktivitas anak dan guru, kemudian dihitung nilai rataratanya melalui rumus:

$$
\mathrm{X}=\frac{\sum X}{N}
$$

Keterangan:

$X \quad$ : Nilai rata-rata

$\Sigma X \quad$ : Jumlah nilai seluruh anak

$\mathrm{N}$ : Jumlah anak 
Setelah diperoleh hasil aktivitas guru dan aktivitas anak maka dapat di interpretasikan persentase ke dalam tabel skala kualifikasi berikut:

Tabel 1. Skala Kualifikasi Penilaian

\begin{tabular}{ccc}
\hline No. & Tingkat Penguasaan & Predikat \\
\hline 1 & $86-100 \%$ & Sangat Baik \\
2 & $76-85 \%$ & Baik \\
3 & $60-75 \%$ & Cukup \\
4 & $55-59 \%$ & Kurang \\
5 & $\leq 54 \%$ & Kurang Sekali \\
\hline
\end{tabular}

Selanjutnya, (2) Analisis Keterampilan Motorik Kasar, digunakan untuk menjawab rumusan masalah mengenai keterampilan motorik kasar anak sebelum diterapkan kegiatan senam ritmik. Selain itu, juga untuk menjawab rumusan masalah mengenai keterampilan motorik kasar anak setelah diterapkan kegiatan senam ritmik yang dilakukan pada setiap siklus dengan menggunakan instrumen berupa hasil unjuk kerja anak dengan rumus:

$$
K M K=\frac{\text { Skor yang dicapai siswa }}{\text { Skor maksimal }} \times 100
$$

Keterangan:

$\mathrm{KMK}=$ Keterampilan Motorik Kasar

Setelah diperoleh skor keterampilan motorik kasar setiap anak, kemudian dihitung nilai rata-ratanya melalui rumus sebagai berikut:

$$
\mathrm{X}=\frac{\sum X}{N}
$$

Keterangan:

X : Nilai rata-rata

$\Sigma \mathrm{X} \quad$ : Jumlah nilai seluruh anak

$\mathrm{N} \quad$ : Jumlah anak

Setelah diperoleh skor keterampilan motorik kasar setiap anak dan nilai rataratanya secara klasikal melalui rumus di atas, hasilnya diinterpretasikan pada skala

\begin{tabular}{|c|c|c|}
\hline No. & Interval & Predikat \\
\hline 1 & $80-100$ & Sangat Baik \\
\hline 2 & $70-79$ & Baik \\
\hline 3 & $60-69$ & Cukup \\
\hline 4 & $50-59$ & Kurang \\
\hline
\end{tabular}
kualifikasi sebagai berikut: 


\begin{tabular}{ccc}
5 & $0-54$ & Kurang Sekali \\
\hline & Sumber: Muhibbin Syah, 2012: 223
\end{tabular}

\section{Hasil dan Diskusi}

Berdasarkan analisis data hasil keterampilan motorik kasar anak sebelum menggunakan kegiatan senam ritmik pada pra siklus belum maksimal. Hal ini menunjukkan keterampilan motorik kasar anak diperoleh nilai rata-rata 46,17 dengan kategori kurang sekali. Metode dalam pengembangan motorik kasar anak yang digunakan dalam pembelajaran kurang diperhatikan oleh guru. Guru lebih memperhatikan pembelajaran pada motorik halus dan kurangnya stimulasi motorik kasar. Hal tersebut terbukti dari hasil observasi awal yang dilakukan oleh penulis. Namun setelah diterapkan kegiatan senam ritmik terjadi peningkatan keterampilan motorik kasar anak dikelompok A RA Jadaria Desa Cibiru Wetan Kecamatan Cileunyi Kabupaten Bandung.

Adapun Penerapan Senam Ritmik untuk Meningkatkan Keterampilan Motorik Kasar pada Anak Kelompok A RA Jadaria Desa Cibiru Wetan Kecamatan Cileunyi Kabupaten Bandung yaitu pada siklus I Penerapan senam ritmik untuk meningkatkan keterampilan motorik kasar dapat dilakukan melalui observasi aktivitas guru dan aktivitas anak yang terdiri dari dua tindakan pada setiap siklusnya. Adapun pemaparan hasil observasi aktivitas guru dan aktivitas anak adalah sebagai berikut: hasil aktivitas guru pada siklus I mengalami peningkatan dengan rincian pada siklus I tindakan I diperoleh nilai rata-rata $70 \%$ dengan kategori cukup dan siklus I tindakan II diperoleh nilai rata-rata $80 \%$ dengan kategori baik. Maka dihitung rata-rata hasil observasi aktivitas guru pada siklus I dalam tabel berikut:

Tabel 3 Rata-rata Hasil Observasi Aktivitas Guru Siklus I

\begin{tabular}{ccc}
\hline No & Tindakan & Hasil Observasi \\
\hline 1 & Tindakan I & $70 \%$ \\
2 & Tindakan II & $80 \%$ \\
& Rata-rata & $75 \%$ \\
\hline
\end{tabular}

Berdasarkan perhitungan di atas, maka tingkat keterlaksanaan aktivitas guru pada siklus I adalah 75\% dengan kategori cukup. Dengan demikian pembelajaan dilanjutkan pada siklus berikutnya. Sedangkan hasil Observasi Aktivitas anak pada siklus I mengalami peningkatan dengan rincian pada siklus I tindakan I diperoleh nilai rata-rata $44,79 \%$ dengan kategori kurang sekali dan siklus I tindakan II diperoleh nilai rata-rata $54,51 \%$ dengan kategori kurang sekali. Maka dihitung rata-rata hasil observasi aktivitas anak pada siklus I dalam tabel berikut: 
Tabel 4 Rata-rata Hasil Observasi Aktivitas Anak Siklus I

\begin{tabular}{ccc}
\hline No & Tindakan & Hasil Observasi \\
\hline 1 & Tindakan I & $44,79 \%$ \\
2 & Tindakan II & $54,51 \%$ \\
& Rata-rata & $49,65 \%$ \\
\hline
\end{tabular}

Berdasarkan perhitungan di atas, maka tingkat keterlaksanaan aktivitas anak pada siklus I diperoleh rata-rata $49,65 \%$ dengan kategori kurang sekali. Dengan demikian pembelajaan dilanjutkan pada siklus berikutnya. Sedangkan pada Siklus II penerapan senam ritmik untuk meningkatkan keterampilan motorik kasar dapat dilakukan melalui observasi aktivitas guru dan aktivitas anak yang terdiri dari dua tindakan pada setiap siklusnya. Hasil aktivitas guru pada siklus II mengalami peningkatan dengan rincian pada siklus II tindakan I diperoleh nilai rata-rata $90 \%$ dengan kategori sangat baik dan siklus II tindakan II diperoleh nilai rata-rata 100\% dengan kategori sangat baik. Maka dihitung rata-rata hasil observasi aktivitas guru pada siklus Il dalam tabel berikut:

\begin{tabular}{|c|c|c|}
\hline No. & Tindakan & Hasil Observasi \\
\hline 1 & Tindakan I & $90 \%$ \\
\hline 2 & Tindakan II & $100 \%$ \\
\hline & Rata-rata & $95 \%$ \\
\hline
\end{tabular}

Berdasarkan perhitungan di atas, maka tingkat keterlaksanaan aktivitas guru pada siklus II adalah 95\% dengan kategori sangat baik. Maka dapat dikatakan aktivitas guru pada siklus II mengalami peningkatan dari siklus sebelumnya. Sedangkan hasil observasi aktivitas anak pada siklus II mengalami peningkatan dengan rincian pada siklus II tindakan I diperoleh nilai rata-rata $63,71 \%$ dengan kategori cukup dan siklus II tindakan II diperoleh nilai rata-rata 79,94\% dengan kategori baik. Maka dihitung rata-rata hasil observasi aktivitas anak pada siklus II dalam tabel berikut:

Tabel 6 Rata-rata Hasil Observasi Aktivitas Anak Siklus II

\begin{tabular}{ccc}
\hline No. & Tindakan & Hasil Observasi \\
\hline 1 & Tindakan I & $63,71 \%$ \\
2 & Tindakan II & $79,94 \%$ \\
& Rata-rata & $71,82 \%$ \\
\hline
\end{tabular}

Berdasarkan Tabel 6 bahwa tingkat keterlaksanaan aktivitas anak pada siklus II diperoleh rata-rata $71,82 \%$ dengan kategori cukup. Maka terjadi peningkatan dari siklus I yang mendapat kriteria kurang sekali ke siklus II yang mendapat kriteria cukup Adapun Keterampilan Motorik Kasar Setelah diterapkan Kegiatan Senam Ritmik pada Anak Kelompok A RA Jadaria Desa Cibiru Wetan Kecamatan Cileunyi Kabupaten Bandung 
pada siklus I keterampilan motorik kasar anak setelah diterapkan kegiatan senam ritmik melalui unjuk kerja anak pada akhir siklus I diperoleh nilai rata-rata sebesar 55,28 dengan kategori kurang. Adapun banyaknya anak yang memiliki keterampilan motorik kasar sesuai dengan kriteria penilaian dapat dilihat pada tabel berikut:

Tabel 7 Keterampilan Motorik Kasar pada Siklus I

\begin{tabular}{ccc}
\hline $\begin{array}{c}\text { Ukuran Keterampilan } \\
\text { Motorik Kasar }\end{array}$ & Jumlah Anak & Kriteria Penilaian \\
\hline $80-100$ & 1 & Sangat Baik \\
$70-79$ & 2 & Baik \\
$60-69$ & 3 & Cukup \\
$50-59$ & 5 & Kurang \\
$0-54$ & 7 & Kurang Sekali \\
\hline
\end{tabular}

Berdasarkan Tabel 7 dapat dilihat bahwa keterampilan motorik kasar anak pada siklus I menunjukkan bahwa terdapat 7 anak dalam kriteria kurang sekali, 5 anak pada kriteria kurang, 3 anak pada kriteria cukup, 2 anak pada ktriteria baik, dan 1 anak pada kriteria sangat baik. Perolehan data ini menunjukkan bahwa adanya peningkatan dari pra siklus. Sedangkan pada Siklus II keterampilan motorik kasar anak setelah diterapkan kegiatan senam ritmik melalui unjuk kerja anak pada akhir siklus II diperoleh nilai ratarata sebesar 78,35 dengan kategori baik. Adapun banyaknya anak yang memiliki keterampilan motorik kasar sesuai dengan kriteria penilaian dapat dilihat pada tabel berikut:

Tabel 8 Keterampilan Motorik Kasar pada Siklus II

\begin{tabular}{ccc}
\hline $\begin{array}{c}\text { Ukuran Keterampilan } \\
\text { Motorik Kasar }\end{array}$ & Jumlah Anak & Kriteria Penilaian \\
\hline $80-100$ & 2 & Sangat Baik \\
$70-79$ & 6 & Baik \\
$60-69$ & 6 & Cukup \\
$50-59$ & 4 & Kurang \\
$0-54$ & - & Kurang Sekali \\
\hline
\end{tabular}

Berdasarkan Tabel 8 dapat dilihat bahwa keterampilan motorik kasar anak pada siklus II menunjukkan bahwa terdapat empat anak dalam kriteria kurang, enam anak pada kriteria cukup, enam anak pada kriteria baik, dan dua anak pada kriteria sangat baik. Perolehan data ini menunjukkan bahwa keterampilan motorik kasar yang dimiliki oleh anak pada setiap siklusnya mengalami peningkatan. Dengan demikian hipotesis 
yang diajukan diterima, artinya kegiatan senam ritmik dapat meningkatkan keterampilan motorik kasar anak.

Dalam pelaksanaan kegiatan senam ritmik hal pertama yang dilakukan oleh guru adalah mengenalkan gerakan senam kepada anak. Kemudian guru mengajak anak untuk mencoba gerakan senam secara bersama-sama. Setelah anak melakukan gerkan-gerakan senam secara berulang-ulang anak menjadi hafal terhadap gerakan senam, dan anak dapat melakukan gerakan senam sendiri tanpa melihat contoh dari guru. Setelah melakukan kegiatan senam rimik, anak-anak kelompok A RA Jadaria mengalami peningkatan dalam hal kemampuan motorik kasarnya. Hal ini terlihat dari keterampilan anak dalam melakukan gerakan-gerakan senam yang meliputi ketepatan, keseimbangan, kontinuitas gerakan, kelenturan. Selain itu, kepercayaan diri anak meningkat setelah melakukan gerakan senam ritmik. Anak yang biasanya hanya terdiam tidak mau bergerak, setelah dilakukan kegiatan senam ritmik menjadi lebih percaya diri dan mau ikut bergerak bersama teman-temannya. Pelaksanaan kegiatan senam ritmik mampu meningkatkan kerjasama antar anak di RA Jadaria. Hal ini terlihat ketika anak yang sudah hapal gerakan senam memberikan contoh terhadap teman yang belum hapal terhadap gerakan-gerakan senam. Kegiatan senam ritmik dapat meningkatkan rasa kedisiplinan anak, hal ini terlihat dari pelaksanaan kegiatan senam ritmik, anak harus mengikuti musik yang digunakan, sehingga anak tidak dapat bergerak sesuai kehendak pribadinya. Anak harus mengikuti gerakan senam yang dicontohkan oleh guru, sehingga terlihat keseragaman gerakan pada setiap anak.

Penelitian ini sejalan dengan penelitian sebelumnya yang dilakukan oleh Suci Permata Sari pada tahun 2016 yang berjudul "Upaya Meningkatkan Motorik Kasar Melalui Senam Irama di Kelompok A TK Pertiwi 21.1 Setda Kabupaten Sragen". Adapun hasil penelitian tersebut yaitu pada unsur ketepatan anak yang memenuhi kategori BSH (Berkembang Sesuai Harapan) sebanyak 22 anak atau $88 \%$ dan anak yang masuk dalam kategori MB (Mulai Berkembang) sebanyak tiga anak atau sebesar $12 \%$ dari jumlah anak. Pada unsur keseimbangan anak yang memenuhi kategori BSH (Berkembang Sesuai Harapan) sebanyak 23 anak atau sebesar 92\% dan anak yang masuk dalam kategori MB (Mulai Berkembang) sebanyak dua anak atau sebesar $8 \%$ dari jumlah anak. Pada kontinuitas gerakan anak yang memenuhi kategori BSH (Berkembang Sesuai Harapan) sebanyak 23 anak atau sebesar 92\% dan kategori MB (Mulai Berkembang) sebanyak dua anak atau sebesar $8 \%$ dari jumlah anak. Pada unsur kelentukan anak yang memenuhi kategori BSH (Berkembang Sesuai Harapan) sebanyak 13 anak atau 52\%, dalam kategori MB (Mulai Berkembang) sebanyak 12 anak 
atau 48\%. Berdasarkan pembahasan diatas, maka keterampilan motorik kasar pada anak kelompok A TK Pertiwi 21.1 Setda Kabupaten Sragen dapat dikatakan baik, karena anak yang memasuki kategori BSH (Berkembang Sesuai Harapan) sudah mencapai 80\%, Sejalan dengan pedoman penilaian di Taman Kanak-kanak (2010: 40). Selain hasil yang dicapai, keberhasilan lain juga dilihat dari keadaan anak-anak yang semakin sehat dan ceria setelah diadakan senam irama. Kegiatan senam irama yang memiliki gerakangerakan senam sederhana dan diiringi oleh musik ceria, pada dasarnya disukai oleh anak-anak, Untuk itu keterampilan motorik kasar pada anak perlu diperkaya dengan inovasi-inovasi agar anak antusias dalam mengikutinya. Dengan melalui aktivitas fisik anak akan terlibat langsung pada pengalaman yang dapat melatih kekuatan otot mereka yang dapat berkembang sesuai harapan. Hal ini sependapat dengan Dekpdiknas (2007: 45) bahwa senam irama memiliki fungsi: (1) untuk melatih kekuatan motorik anak, (2) untuk melatih kecepatan motorik anak, (3) untuk melatih kelentukan motorik anak, dan (4) untuk melatih keseimbangan motorik anak.

\section{Penutup}

Berdasarkan hasil analisis data tentang penerapan kegiatan senam ritmik untuk meningkatkan keterampilan motorik kasar anak yang dilakukan di RA Jadaria, dapat disimpulkan sebagai berikut: (1) Keterampilan motorik kasar anak sebelum diterapkan kegiatan senam ritmik di kelompok A RA Jadaria diinterpretasikan dalam kategori kurang sekali. Hal ini dibuktikan dengan hasil penilaian motorik kasar anak dengan nilai 46,17. (2) Penerapan senam ritmik untuk meningkatkan keterampilan motorik kasar anak dilihat dari aktivitas guru dan aktivitas anak mengalami peningkatan setiap siklusnya. Hal ini ditunjukkan oleh aktivitas guru pada siklus I diperoleh rata-rata sebesar $75 \%$ dengan kriteria cukup, dan pada siklus II diperoleh rata-rata sebesar 95\% dengan kriteria sangat baik. Demikian pula hasil analisis aktivitas anak pada siklus I diperoleh rata-rata sebesar $49,65 \%$ dengan kategori kurang sekali, dan pada siklus II diperoleh rata-rata sebesar $71,82 \%$ dengan kategori cukup. (3) Hasil keterampilan motorik kasar anak setelah diterapkan kegiatan senam ritmik di kelompok $A$ RA Jadaria setiap siklusnya mengalami peningkatan. Hal tersebut dibuktikan dengan hasil penilaian pada akhir siklus I diperoleh nilai rata-rata 55,28 dengan kategori kurang. Sedangkan pada siklus akhir II diperoleh nilai rata-rata 78,35 dengan kategori baik. Hal tersebut membuktikan bahwa kegiatan senam ritmik dapat meningkatkan keterampilan motorik kasar anak.

Berdasarkan kesimpulan di atas ada beberapa saran yang ingin peneliti uraikan yaitu: (1) Dalam merencanakan kegiatan yang berhubungan dengan motorik kasar, 
hendaknya dibuat kegiatan yang menarik perhatian sehingga anak aktif dalam pembelajaran, salah satu cara yang membuat anak aktif dan membuat anak senang yaitu dengan menggunakan kegiatan senam ritmik. (2) Dalam penerapan senam ritmik guru harus dapat mengatur dan mengalokasikan waktu dengan baik, karena dalam penerapan kegiatan pembelajaran ini memerlukan waktu yang cukup efektif dan efisien, sehingga jika tanpa bimbingan dari guru maka pembelajaran tidak akan mencapai hasil yang maksimal. (3) Setelah diterapkan kegiatan senam ritmik ketika anak yang sudah hapal gerakan senam ditempatkan di barisan yang paling depan agar memberikan contoh terhadap teman yang belum hapal terhadap gerakan-gerakan senam. Hal tersebut ditujukan untuk meningkatkan keterampilan motorik kasar setiap anak. Keterampilan motorik kasar sangat penting bagi perkembangan anak, oleh karena itu peneliti selanjutnya diharapkan dapat membuat penelitian mengenai keterampilan motorik kasar melalui metode atau kegiatan lain yang lebih menarik bagi anak.

\section{Daftar Pustaka}

Akbar, S. 2010. Penelitian Tindakan Kelas Filosofi, Metodologi, Implementasi. Yogyakarta: CV Cipta Medika.

Arikunto, S. 2010. Penelitian Tindakan untuk Guru, Kepala Sekolah dan Pengawas. Yogyakarta: Aditya Media.

Creswell, J. 2016. Research Design. Yogyakarta: Pustaka Pelajar.

Peraturan Menteri Pendidikan dan Kebudayaan Republik Indonesia Nomor 137 Tahun 2014 Tentang Standar Nasional Pendidikan Anak Usia Dini.

Kamtini. 2005. Bermain Melalui Gerak Dan Lagu Di Taman Kanak-kanak. Jakarta: Depdikbud.

Mulyasa, E. 2011. Praktik Penelitian Tindakan Kelas. Bandung: Rosda. 2014. Manjemen PAUD. Bandung: Rosda.

Permendiknas No. 58 Tahun 2009 tanggal 17 September 2009 Tentang Standar Pendidikan Anak Usia Dini.

Purwanto, N. 2009. Prinsip-Prinsip dan Teknik Evaluasi Pengajaran. Bandung: PT Remaja Rosdakarya.

Sari, S. P. 2016. Upaya Meningkatkan Motorik Kasar Melalui Senam Irama. Skripsi. Yogyakarta: Fakultas IImu Pendidikan Universitas Negeri Yogyakarta

Sugiyono. 2016. Metode Penelitian Pendidikan. Bandung: Alfabeta. . 2017. Metode Penelitian Kuantitatif, Kualitatif, R\&D. Bandung: Alfabeta. 
Sumantri. 2005. Model Pengembangan Keterampilan Motorik Anak Usia Dini. Jakarta: Depdiknas.

Syah, M. 2012. Psikologi Belajar. Jakarta: Raja Grafindo Persada.

Umar, B. 2012. Hadis Tarbawi. Jakarta: Amzah.

\section{Biodata Penulis}

Agni Firdaus, penulis dilahirkan di Subang pada tanggal 19 September 1996. Anak pertama dari 2 bersaudara. Penulis adalah anak dari pasangan suami istri Bapak Didi Junaidi (Alm) dan Ibu Maryam. Adapun pendidikan formal penulis yaitu SDN Kertajaya yang bertempat di kabupaten subang tahun lulus 2007/2008, MTSs Bhakti Satria yang bertempat di kabupaten subang tahun lulus 2010/2011, MA Al-Jawami yang betempat di kabupaten bandung tahun lulus 2013/2014, dan UIN Sunan Gunung Djati Bandung jurusan Pendidikan Islam Anak Usia Dini lulus 2018. 